\title{
Challenges in preventing vertical HIV transmission in Petrolina, Pernambuco and Juazeiro, Bahia
}

Mucio do Nascimento Brandão 1

Edvaldo da Silva Souza 2

Rodrigo José Videres de Brito 3

Cavalcanti, Martha Maria de Souza Guimarães 4

Maria de Fátima Ramos Brandão 5

Magna Cavalcante e Cavalcante 6

\footnotetext{
1,3-5 Universidade Federal do Vale do São Francisco (UNIVASF). Av. José de Sá Maniçoba, s/n. Centro. Petrolina, PE, Brasil. CEP: 56304-917. E-mail: munabran@uol.com.br 2 Instituto de Medicina Integral Professor Fernando Figueira (IMIP). Recife, PE, Brasil.
}

${ }^{6}$ Secretaria Municipal de Saúde de Saúde - Programa de DST/HIV/AIDS. Juazeiro, BA, Brasil.

\begin{abstract}
Objectives: to measure vertical HIV transmission rate (TTV) and describe the adoption of prophylactic measurements (MP) in infected pregnant women and exposed children in the cities of Petrolina, PE and Juazeiro, BA.

Methods: a cross-sectional study was carried out on 76 mothers and children from January 2006 to December 2010. Data were collected from reported forms and medical records from the referral services. The Ministry of Health recommendations was followed to characterize an infected child. It was appropriately considered to adopt the five MP distributed in three stages of care: pregnancy (antiretroviral therapy), intrapartum (intravenous azidotimidina and by delivery preference as a function of the maternal viral load) and post natal (azidotimidina taken orally by children and no breastfeeding).

Results: 58 children investigated, five were HIV infected, revealing $8.6 \%$ of TTV. The MP was inadequate in $68.4 \%$ of the cases.

Conclusions: high TTV of HIV and inadequate MP in most of the cases, the non-white patients and those who came from other cities received a lower proportion of adequate MP. Diagnostic failures and the three stages of care reflected on the TTV. Improve quick tests at pregnancy, integrate actions in cities, offer reproductive planning, maximize coverage of prenatal care and engage obstetric teams and Family Health are strategies to reduce TTV.

Key words HIV infections, Prenatal care, Vertical transmission of infectious diseases, Transmitted disease control, Brazil
\end{abstract}




\section{Introduction}

The control of vertical transmission (TV) of the human immunodeficiency virus (HIV) still defies various countries. In 2014, there was an estimate of 35.0 million people with HIV living in the planet. 3.2 million were children under 15 years of age, most of them are contaminated by TV living in poor or in developing countries, including Brazil. ${ }^{1}$

It is known that $65 \%$ to $70 \%$ of TV occurs at the delivery, contacted by maternal blood of the cutaneous mucosa surface of the unborn child, 35\% intrauterine - especially in the last weeks of pregnancy - and by breastfeeding which attributes to additional risk of TV between $5 \%$ and $22 \% .^{2-3}$ The high maternal viral load (CV) and the rupture of the extended membranes are the factors mostly associated to TV of HIV.4-5 This transmission may occur between $20 \%$ to $25 \%$ of the cases without intervention. 6-7

In 1994, the AIDS Clinical Trial Group (ACTG 076) published a study showing the effectiveness of azidotimidina (AZT) in reducing TV of HIV in $67.5 \%$ of the cases, with transmission rates of $25.5 \%$ in the placebo group and $8.3 \%$ in the AZT group. 6 Since then, evidence has reasoned with the five preventive measurements (MP), when adopted altogether, the levels of TV had dropped below $2 \%$ in developing countries and between 0 and $1 \%$ in developed countries. ${ }^{8}$ At first, the use of antiretroviral combination therapy (TARV) in pre-natal care, was taken during the first 13 weeks and associating it with at least three other antiretroviral drugs (ARV) in different moments until the delivery. ${ }^{7,9}$ At the monent of the delivery, it was recommended the use of intravenous AZT in the parturient's intrapartum (except for those with undetectable $\mathrm{CV}$ after 34 weeks), followed by the parturition preference (elective cesarean section (CE) - with integrated membranes and after 38 weeks of gestation will be performed if the maternal CV is greater than 1,000 copies $/ \mathrm{mL}$ or ignored until 34 weeks - or, vaginal/cesarean section, if the $\mathrm{CV}$ is less than 1,000 copies/mL until the $34^{\text {th }}$ week). In postpartum period the use of AZT syrup is recommended for the newborn (RN) - associating with nevirapine in case the mother has not taken TARV or the CV is greater than 1,000 copies/mL - and not breastfeeding. $10-13$

To enable the adoption of the MP, prenatal should be initiated early, continuous and universally. In Brazil, all pregnant women should perform serological screening in the first trimester of their pregnancy. 13 In 2002, the Projeto-Nascer Maternidades (PNM) was introduced to detect non-screened cases in pregnant women, and to ensure the parturients, the MP of TV, except for TARV. 14 In 2009 the use of the rapid tests to diagnose quickly was established, especially in areas of difficult access to laboratories and, since 2012, the States and cities received incentives to aim among other actions to optimize diagnosis, as well as in primary care and childbirth admission. ${ }^{15-}$ 16

Nationwide in 2004, TV of HIV was estimated at $6.8 \%$, ranging from $13.4 \%$ in the North Region to $4.3 \%$ in the Midwest. ${ }^{17}$ In the same year, the effective coverage to detect pregnant women was evaluated, socio-spacial inequalities were also evident among the regions with $24 \%$ coverage in the Northeast and $72 \%$ in the South. 18

In the 1990s the tracking of HIV cases began in the region of the sub-medium part of the San Francisco River with the construction of two Counseling and Testing Centers in the cities of Juazeiro, BA and Petrolina, PE, and along with the Specialized Care Services (SAE) to monitor and accompany HIV positive mothers and their children. In the following decade, the first cases of TV were detected. In 2002, Dom Malan Hospital (HDM) in Petrolina became a regional reference (PNM) for obstetric care. From 2006 to 2010, 36,150 pregnant women attended the prenatal care, however only $27 \%$ were tested for HIV. 19

The unknown vertical transmission rate (TTV) of HIV and the absence of research studies describing the adoption of MP in these two cities have raised the need to do this study, aiming to assess such rate and to describe the implementation of these measurements in mothers with HIV and the exposed children.

\section{Methods}

This is a cross-sectional study carried out on 76 HIV positive mothers and exposed children in the period of January 2006 to December 2010, in the cities of Petrolina, Pernambuco and Juazeiro, Bahia, in the sub-medium micro region of the San Francisco River, in the Northeast of Brazil. The protocol was approved by the Research Ethics Committee at the Universidade Federal do Vale do São Francisco (Federal University of San Francisco Valley).

The inclusion criteria were HIV positive mothers and/or children exposed to HIV at the time of childbirth. 76 pairs of mothers/children were identified, 61 were of the Report Forms and Research Investigation (FNI) of the Epidemiological Surveillance (VE) and 15 were from children's SAE medical records from the two cities. There were no 
multiple pregnacies. HIV positive mother with serologic evidence revealed in screening prior to the pregnancy was defined, during the prenatal, at childbirth, or after birth, by immunoenzymatic test (ELISA) in two successive positive tests in a first blood sample, followed by a confirmatory test (indirect immunofluorescence, Imunoblot or Western blot) in a new sample, or by two quick successive positive tests following the Ministry of Health (MS) recommendations. 20

The study population excluded, in measuring TTV, 18 cases without conclusion on children's investigation (10 losses for follow-up, two moved away and six investigations in progress), totaling 58 cases selected in this subpopulation. To evaluate MP, there were no exclusions according to the flow chart (Figure 1).

To define children's infection, the recommendations from the MS were also followed. It was defined as "infected" with two detectable CV in two blood samples during the first year of life, or with positive serology for HIV after 18 months of age, and also children that died with AIDS (clinical diagnosis) with the exposure to HIV confirmation and without CV diagnosed. It was defined as "not infected" with two samples of undetectable $\mathrm{CV}$ in the first year of life and/or with negative serology for HIV after 12 months of age. 20

It was defined as "adequate" the adoption of the five MP covering the three stages of care: Stage 1 (pregnancy): the use of TARV; Stage 2 (labor): the use of AZT intravenous in mothers followed by the option of preferred delivery or acceptable in the $\mathrm{CV}$ function of maternal measurement of until the $34^{\text {th }}$ week (CE from 38 weeks and CV greater than 1,000 copies $/ \mathrm{mL}$ or ignored, cesarean or vaginal delivery if $\mathrm{CV}$ is less than 1,000 copies $/ \mathrm{mL}$ ); Stage 3 (postpartum): Children taking AZT orally (initiated in the maternities and maintained for 42 days) and no breastfeeding. The non-adopting was defined as "inadequate", the inapplicability or the lack of information on any measurements making the MP inapplicable when the maternal diagnosis occurred after the recommended stage for its use. At the time of the completion and the comprehensive period of this study, the current MS recommendations did not give AZT to mothers' intrapartum with undetectable CV and associated nevirapine to oral AZT in children whose mothers did not take TARV or presented CV greater than 1,000 copies $/ \mathrm{mL}$, which that is why these procedures were not included in the definition of adequacy. 13,20

Based on constant information from the FNI and the available medical records on mothers and chil- dren, the research was based on sociodemographic variables such as: age, schooling, ethnicity (white or non-white, according to the information from FNI) and where from (cities or other places); services and care: prenatal care (yes or no), time of diagnosis on maternal infection, gestational age at diagnosis, measurement of maternal CV until 34 weeks (more or less than 1,000 copies $/ \mathrm{mL}$ ) and maternity (location) of birth; the preventive measurements: the use of AZT endovenous in the mother's intrapartum through preferential delivery and /or acceptable (CE when maternal $\mathrm{CV}$ is greater than 1,000 or vaginal/cesarean section is less than 1,000 copies $/ \mathrm{mL}$ ) the use of oral AZT in children (from the delivery until 42 days) and no breastfeeding; investigation on children: two $\mathrm{CV}$ measurements (first year of life) performed serological screening after one year and clinical criteria (died of AIDS). The variables were the mother's employment/occupation, drug use, sexual partner and the number of prenatal visits were not included for the lack of or/and insufficient data in the researched documents.

Tables were developed on the distribution of frequencies with categorical variables presented in absolute and relative values, and the numeric values in a central tendency and dispersion. Variables related to diagnosis were crossed and the use/adequacy of the MP along with the assistance services, maternal characteristics and elaborated tables with resulting data. The statistical program EpiInfo version 3.5.3 for Windows was used.

\section{Results}

The mothers' age (Table 1) ranged from 15 to 41 years old (average: $26.8+6.8$ ), the predominant frequency of $47.3 \%(35 / 74)$ in the range of 26 to 35 years old; $77.6 \%(52 / 67)$ had up to eight years of schooling; $88.2 \%(60 / 68)$ were non-whites and $81.6 \%(62 / 76)$ lived in both cities. $60.5 \%(46 / 76)$ were followed up in Petrolina and 39.5\% (30/76) in Juazeiro. 97.1\% (67/69) reported receiving prenatal treatment without specifying the number of consultations. $39.5 \%(30 / 76)$ of the diagnosis occurred before the pregnancy; $34.2 \%(26 / 76)$ during pregnancy; $19.7 \%(15 / 76)$ at the delivery and $6.6 \%$ $(5 / 76)$, at postpartum, a mean of $28.0 \pm 8.9$ (minimum: 20; maximum: 40) weeks of gestational age diagnosed in those screened during pregnancy or at childbirth (26). The maternal CV measured until the 34th week of pregnancy was greater than 1,000 copies $/ \mathrm{mL}$ in $16.6 \%(8 / 48)$ and less than in $41.7 \%$ (20/48). $55.7 \%(39 / 70)$ of the mothers had their babies in a referral maternity, $35.7 \%(25 / 70)$ had in 


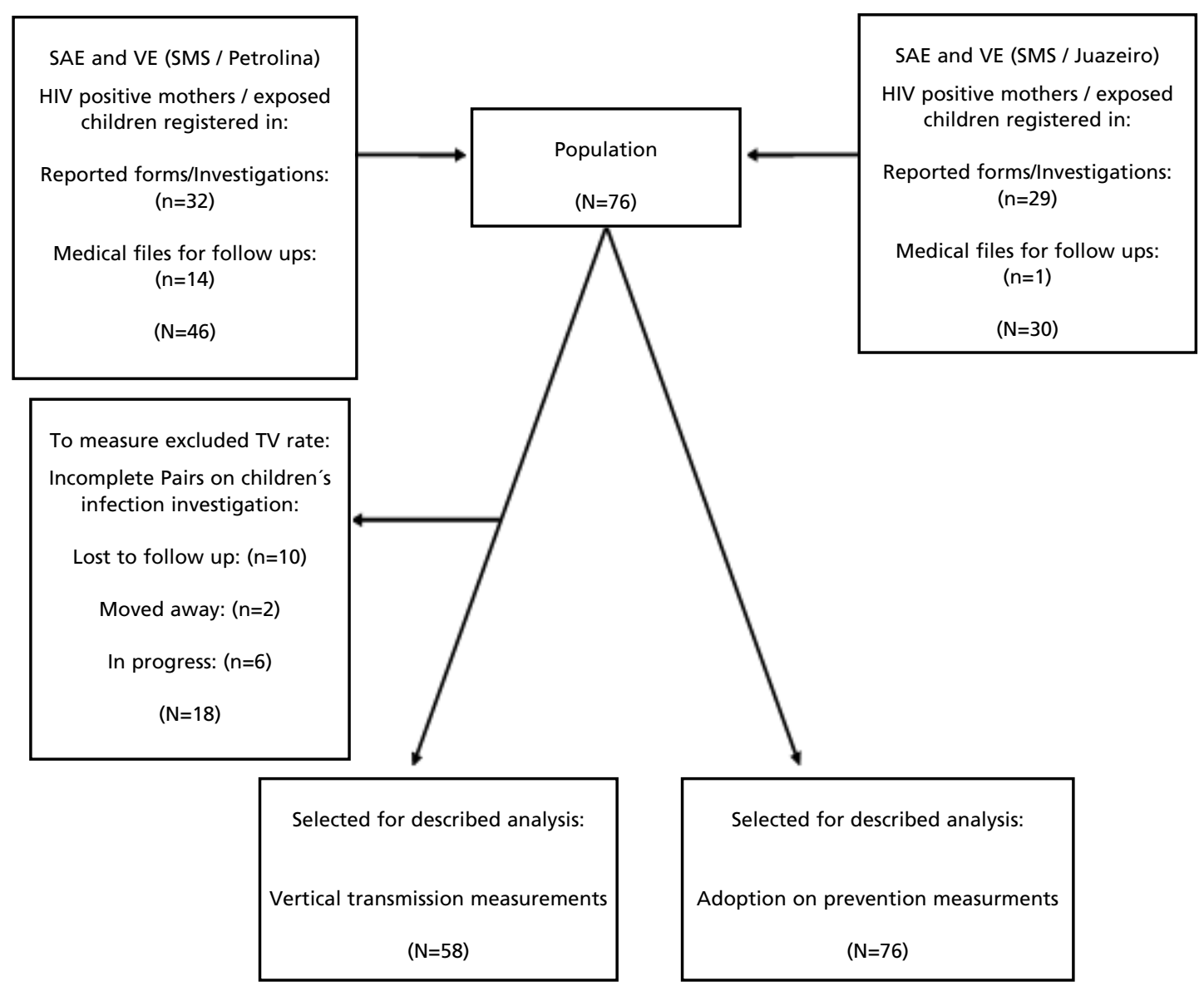

SAE= Specialized Care Service; VE= Epidemiological Surveillance; SMS= Municipal Health Department; $T V=$ vertical transmission.

hospitals linked to a Unified Health System (SUS); $5.7 \%(4 / 70)$ had in private services and $2.9 \%(2 / 70)$ had at home.

In the subpopulation of 58 children in a thorough research, five were infected, meaning $8.6 \%$ of TTV (Table 2). Two of them had clinical diagnoses, without measuring the CV (died of AIDS). The stratification showed four in Petrolina and one in Juazeiro, meaning that local TTV were $11.4 \%(4 / 35)$ and $4.4 \%(1 / 23)$ respectively.

In 76 cases (Table 3 ), the TARV was adopted in $56.6 \%$ (43), 13.5 weeks was the median time to apply (Min: 2; Max: 29; IQ: 8-24) in 38 based on this information; $61.8 \%(47)$ received AZT intrapartum and delivery type was acceptable by $52.6 \%$
(40) of the pregnant women; $63.1 \%$ (48) of the children received AZT orally and $79.0 \%$ (60) were not breastfed. Stage 1 was completed in $56.6 \%$ (43), Stage 2 in $44.7 \%$ (34) and Stage 3 in $60.5 \%$ (46). The adoption was adequate in $31.6 \%$ (24) and inadequate in $68.4 \%$ (52) of the pairs.

Table 4 shows that in Petrolina, only the type of delivery achieved a higher percentage than in Juazeiro (54.4\% against 50.0\%). The other MP, the percentages were less: TARV (54.4\% against $60 \%$ ), AZT intrapartum (52.2\% against $76.7 \%$ ); oral AZT (58.7\% against $70.0 \%)$ and no breastfeeding $76.1 \%$ against $83.3 \%$ ). In the overall adoption, there was a greater adequacy in Juazeiro (40.0\% against 26.1\%).

Crossing the age groups, other than TARV, the 
Sociodemographic characteristics and assitance to 76 mothers with HIV in the cities of Petrolina, PE and Juazeiro, BA, from January 2006 to December 2010.

\begin{tabular}{|c|c|c|c|c|c|}
\hline \multirow{2}{*}{ Characteristics $(\mathrm{N})^{*}$} & \multirow[t]{2}{*}{$\mathbf{N}$} & \multicolumn{2}{|c|}{ With information } & \multirow[t]{2}{*}{$\bar{X} \pm S D$} & \multirow[t]{2}{*}{ Min-Max } \\
\hline & & $\mathrm{n}$ & $\%$ & & \\
\hline Maternal age in years & 76 & 74 & - & $6.8 \pm 26.8$ & $15-41$ \\
\hline Age (years) & 76 & 74 & 100.0 & & \\
\hline 15 to 25 & 33 & & 44.6 & & \\
\hline 26 to 35 & 35 & & 47.3 & & \\
\hline 35 to 41 & 6 & & 8.1 & & \\
\hline Ignored & 2 & & - & & \\
\hline Schooling (years) & 76 & 67 & 100.0 & & \\
\hline Up to 8 & 52 & & 77.6 & & \\
\hline$>8$ & 15 & & 22.4 & & \\
\hline Ignored & 9 & & - & & \\
\hline Ethnicity & 76 & 68 & 100.0 & & \\
\hline Non-white & 60 & & 88.2 & & \\
\hline White & 8 & & 11.8 & & \\
\hline Ignored & 8 & & - & & \\
\hline Where from: & 76 & 76 & 100.0 & & \\
\hline Cities-polo & 62 & & 81.6 & & \\
\hline Cities surrounding & 11 & & 14.5 & & \\
\hline Other cities/Other States & 3 & & 3.9 & & \\
\hline Health care service & 76 & 76 & 100.0 & & \\
\hline SAE Petrolina & 46 & & 60.5 & & \\
\hline SAE Juazeiro & 30 & & 39.5 & & \\
\hline Some prenatal care & 76 & 69 & 100.0 & & \\
\hline Yes & 67 & & 97.1 & & \\
\hline No & 2 & & 2.9 & & \\
\hline Ignored & 7 & & - & & \\
\hline At the time of maternal diagnosis & 76 & 76 & 100.0 & & \\
\hline At pre-conception & 30 & & 39.5 & & \\
\hline At Pregnancy & 26 & & 34.2 & & \\
\hline At Childbirth & 15 & & 19.7 & & \\
\hline At postpartum period & 5 & & 6.6 & & \\
\hline Gestational age in weeks in diagnosis & 76 & 26 & - & $8.9 \pm 28.0$ & $20-40$ \\
\hline Maternal viral load with 34 weeks & 76 & 48 & 100.0 & & \\
\hline$>1,000$ copies $/ \mathrm{mL}$ & 8 & & 16.6 & & \\
\hline$<1,000$ copies $/ \mathrm{mL}$ & 20 & & 41.7 & & \\
\hline Inapplicable* & 20 & & 41.7 & & \\
\hline Ignored & 28 & & - & & \\
\hline Maternity or place of birth & 76 & 70 & 100.0 & & \\
\hline Reference (PNM) & 39 & & 55.7 & & \\
\hline Linked to (SUS) & 25 & & 35.7 & & \\
\hline Other hospitals/maternities & 4 & & 5.7 & & \\
\hline Home & 2 & & 2.9 & & \\
\hline Ignored & 6 & & - & & \\
\hline
\end{tabular}

*Diagnostic after pregnancy; SAE= Specialized Care Service; SUS= Unified Health System; PNM= Projeto Nascer Maternidades.. 
Table 2

Vertical HIV transmission in the subpopulation of 58 pairs of HIV positive mothers and exposed children with complete investigation in the cities of Petrolina, PE and Juazeiro, BA (January 2006 to December 2010).

\begin{tabular}{|c|c|c|}
\hline Characteristics & $\mathbf{N}$ & $\%$ \\
\hline Investigated results on children (overall) & 58 & 100.0 \\
\hline Infected (vertical transmission) & 5 & 8.6 \\
\hline Criteria of two viral loads* & 2 & 3.5 \\
\hline Serological criteria & 1 & 1.7 \\
\hline Clinical criteria (died of AIDS) & 2 & 3.4 \\
\hline Non- Infected & 53 & 91.4 \\
\hline Results in Petrolina & 35 & 100.0 \\
\hline Infected (vertical transmission) & 4 & 11.4 \\
\hline Criteria of two viral loads* & 2 & 5.7 \\
\hline Serological criteria & 1 & 2.9 \\
\hline Clinical criteria (died of AIDS) & 1 & 2.9 \\
\hline Non-Infected & 31 & 88.6 \\
\hline Results in Juazeiro & 23 & 100.0 \\
\hline Infected (vertical transmission) & 1 & 4.4 \\
\hline Clinical criteria (died of AIDS) & 1 & 4.4 \\
\hline Non-Infected & 22 & 95.6 \\
\hline
\end{tabular}

* Confirmed by serology.

percentages were close $(57.6 \%$ against $58.6 \%)$ in young girls aged 15 to 25 years old, children and other MP were proportionally and appropriately more adopted and adequate than those who were older: $72.7 \%$ took AZT intrapartum against $56.1 \%$ ); the type of delivery was acceptable in $57.6 \%$ against $51.2 \% ; 69.7 \%$ of the children received oral AZT against $61 \%$; $87.9 \%$ did not breastfeed against $48.8 \%$ and the adoption altogether was adequate to $36.4 \%$ against $29.3 \%$.

With the exception of the type of delivery (55.8\% against $60.0 \%$ ), mothers with less schooling had higher proportions of adopting the preventive measurements: TARV (61.5\% against $60 \%)$, AZT intrapartum $(65.4 \%$ against $60.0 \%)$, oral AZT, $(65.4 \%$ against $53.3 \%)$ and no breastfeeding $(80.8 \%$ against $73.3 \%$ ). In the overall adoption it was nearly balanced $(32.7 \%$ in the less and $33.3 \%$ in the most instructed).

White mothers and their children were proportionally more in favor than the non-whites, between the adoption of the MP and the overall adoption: TARV was fulfilled by $87.5 \%$ against $58.3 \%$; the
AZT intrapartum managed $87.5 \%$ against $63.3 \%$; the type of delivery contemplated in $75.0 \%$ against $53.3 \%$; the oral AZT reached $100.0 \%$ against $58.3 \%$; no breastfeeding reached $87.5 \%$ against $76.7 \%$ and the overall adoption was adequate in $75.0 \%$ against $30.0 \%$ of the others.

Patients from both cities had higher application and adequacy rates of the MP than other result: $59.7 \%$ received TARV against $35.7 \%$; AZT intrapartum was applied in $40.3 \%$ against $35.7 \%$; the type of delivery in $54.8 \%$ against $35.7 \%$; oral AZT in $64.5 \%$ against $50.0 \%$; no breastfeeding in $95.2 \%$ against $57.1 \%$ and $35.5 \%$ of adequacy against $14.3 \%$. 
The adoption of prophylactic measurements of TV on isolated HIV in stages of care and together with a population of 76 pairs of HIV positive mothers and exposed children in the cities of Petrolina, PE and Juazeiro, BA, from January 2006 to December 2010

\begin{tabular}{|c|c|c|c|c|c|}
\hline Characteristics & $\mathrm{N}=76$ & $\%$ & Median & Min-Máx & IQ \\
\hline \multicolumn{6}{|l|}{ TARV } \\
\hline Yes & 43 & 56.6 & & & \\
\hline No & 8 & 10.5 & & & \\
\hline Inapplicable* & 20 & 26.3 & & & \\
\hline Ignored & 5 & 6.6 & & & \\
\hline Time of application of TARV in weeks (38 cases) & & & 13.5 & $2-29$ & $8-24$ \\
\hline \multicolumn{6}{|l|}{ AZT venous in mother intrapartum } \\
\hline Yes & 47 & 61.8 & & & \\
\hline No & 10 & 13.2 & & & \\
\hline Inapplicable* & 5 & 6.6 & & & \\
\hline Ignored & 14 & 18.4 & & & \\
\hline \multicolumn{6}{|l|}{ Acceptable delivery type } \\
\hline Yes & 40 & 52.6 & & & \\
\hline No & 30 & 39.5 & & & \\
\hline Inapplicable* & 5 & 6.6 & & & \\
\hline Ignored & 1 & 1.3 & & & \\
\hline \multicolumn{6}{|l|}{ Oral AZT in children } \\
\hline Yes & 48 & 63.1 & & & \\
\hline No & 12 & 15.8 & & & \\
\hline Ignored & 16 & 21.1 & & & \\
\hline \multicolumn{6}{|l|}{ No breastfeeding } \\
\hline Not breastfed & 60 & 79.0 & & & \\
\hline Breastfed & 8 & 10.5 & & & \\
\hline Ignored & 8 & 10.5 & & & \\
\hline \multicolumn{6}{|l|}{ Stage 1 (pregnancy): TARV } \\
\hline Yes & 43 & 56.6 & & & \\
\hline No/ Inapplicable*/Ignored & 33 & 43.4 & & & \\
\hline \multicolumn{6}{|l|}{ Stage 2 (labor): AZT venosus in mother + acceptable } \\
\hline \multicolumn{6}{|l|}{ delivery type } \\
\hline Yes & 34 & 44.7 & & & \\
\hline No/ Inapplicable*/Ignored & 42 & 55.3 & & & \\
\hline \multicolumn{6}{|l|}{ Stage 3 (post-natal): oral AZT in children + No } \\
\hline \multicolumn{6}{|l|}{ breastfeeding } \\
\hline Yes & 46 & 60.5 & & & \\
\hline No/ Ignored & 30 & 39.5 & & & \\
\hline \multicolumn{6}{|l|}{ Adoption altogether (three stages complete) } \\
\hline Adequate & 24 & 31.6 & & & \\
\hline Inadequate & 52 & 68.4 & & & \\
\hline
\end{tabular}

*Diagnosis after the stage recommended for application of the MP; TV= vertical transmission; HIV= human immunodeficiency virus; TARV= antiretroviral therapy; $A Z T=$ azidotimidina. 
Table 4

Adoption and adaptation of prophylactic measurements of vertical HIV transmission in 76 pairs of HIV positive mothers and exposed children for assistance services and maternal characteristics in the cities of Petrolina, PE and Juazeiro, BA from January 2006 to December 2010.

\begin{tabular}{|c|c|c|c|c|c|c|c|c|c|c|c|c|c|c|c|c|c|c|c|c|}
\hline \multirow[t]{3}{*}{ Characteristics } & \multirow{2}{*}{\multicolumn{2}{|c|}{$\begin{array}{c}\text { SAE } \\
\text { Petrolina }\end{array}$}} & \multirow{2}{*}{\multicolumn{2}{|c|}{$\begin{array}{c}\text { SAE } \\
\text { Juazeiro }\end{array}$}} & \multicolumn{4}{|c|}{ Age range $(74)^{*}$} & \multicolumn{4}{|c|}{ Schooling (67)* } & \multicolumn{4}{|c|}{ Ethnicity (68)* } & \multicolumn{4}{|c|}{ Where from $(76)^{*}$} \\
\hline & & & & & \multicolumn{2}{|c|}{$15-25$ years } & \multicolumn{2}{|c|}{$26-41$ years } & \multicolumn{2}{|c|}{ Up to 8 years } & \multicolumn{2}{|c|}{$>8$ years } & \multicolumn{2}{|c|}{ White } & \multicolumn{2}{|c|}{ Non- White } & \multicolumn{2}{|c|}{ City polo } & \multicolumn{2}{|c|}{ Surr../Other } \\
\hline & 46 & $\%$ & 30 & $\%$ & 33 & $\%$ & 41 & $\%$ & 52 & $\%$ & 15 & $\%$ & 8 & $\%$ & 60 & $\%$ & 62 & $\%$ & 14 & $\%$ \\
\hline \multicolumn{21}{|l|}{ TARV } \\
\hline Yes & 25 & 54.4 & 18 & 60.0 & 19 & 57.6 & 24 & 58.6 & 32 & 61.5 & 9 & 60.0 & 7 & 87.5 & 35 & 58.3 & 37 & 59.7 & 5 & 35.7 \\
\hline \multicolumn{21}{|c|}{ AZT venous intrapartum } \\
\hline Yes & 24 & 52.2 & 23 & 76.7 & 24 & 72.7 & 23 & 56.1 & 34 & 65.4 & 9 & 60.0 & 7 & 87.5 & 38 & 63.3 & 25 & 40.3 & 5 & 35.7 \\
\hline \multicolumn{21}{|c|}{ Acceptable $f$ delivery type } \\
\hline Yes & 25 & 54.4 & 15 & 50.0 & 19 & 57.6 & 21 & 51.2 & 29 & 55.8 & 9 & 60.0 & 6 & 75.0 & 32 & 53.3 & 34 & 54.8 & 5 & 35.7 \\
\hline \multicolumn{21}{|c|}{ Oral AZT in children } \\
\hline Yes & 27 & 58.7 & 21 & 70.0 & 23 & 69.7 & 25 & 61.0 & 34 & 65.4 & 8 & 53.3 & 8 & 100.0 & 35 & 58.3 & 40 & 64.5 & 7 & 50.0 \\
\hline \multicolumn{21}{|l|}{ No breastfeeding } \\
\hline Not breastfed & 35 & 76.1 & 25 & 83.3 & 29 & 87.9 & 20 & 48.8 & 42 & 80.8 & 11 & 73.3 & 7 & 87.5 & 46 & 76.7 & 59 & 95.2 & 8 & 57.1 \\
\hline \multicolumn{21}{|l|}{ Adoption } \\
\hline Adequate & 12 & 26.1 & 12 & 40.0 & 12 & 36.4 & 12 & 29.3 & 17 & 32.7 & 5 & 33.3 & 6 & 75.0 & 18 & 30.0 & 22 & 35.5 & 2 & 14.3 \\
\hline Inadequate & 34 & 73.9 & 18 & 60.0 & 21 & 63.6 & 29 & 70.7 & 35 & 67.3 & 10 & 66.7 & 2 & 25.0 & 42 & 70.0 & 40 & 64.5 & 12 & 85.7 \\
\hline
\end{tabular}

* Cases with variable information; SAE= Specialized Care Service; HIV= human immunodeficiency virus; TARV= antiretroviral therapy; $A Z T=$ azidotimidina. 


\section{Discussion}

The sociodemographic characteristics described do not differ from the pattern revealed in other paper: women were mostly non-white, young, with great reproduction, potentially aligned to no or very little schooling, representing present and future risks of $\mathrm{TV}$, whether not knowing about HIV or having the possibility of successful pregnancies and low quality of prenatal care. 21-23 This requires, in addition, the adoption of MP and counseling for mothers to participate in family planning. The information on partners' condition and the use of drugs were not completed on the data due to the lack of information.

The $8.6 \%$ of TTV measured between 2006 and 2010 surpassed the estimates for 2004 at $6.8 \%$ (Nationwide) and 7.7\% (Northeast), extrapolating goals established by the MS for 2012, to reach rates of $2.7 \%$ and $3.1 \%$ in Brazil and the Northeast, respectively. 17 A cohort with 1,475 HIV positive parturients and their newborns attended from 1996 to 2003 in 17 public maternity hospitals in four representative capitals of the most populous regions in the country, demonstrated in 2005, a coefficient average of $5.6 \%$, although $5.5 \%$ is of the capital in the Northeast. 24 Since then, breakthroughs have been stated. By measuring the detection rate of AIDS in children less than five years of age, the MS observed TV on HIV between 2005 and 2014, a declining tendency of $33.3 \%$. There are, however, important regional differences in the Northeast Region where the decrease is more discreet $(12.1 \%) .25$

Within the expectations of the goals, in 2008, TTV was measured in $2.5 \%$ in Fortaleza, 21 and, in 2012 , the coefficient was $1.8 \%$ in Aracaju. 22 In contrast with these results in metropolitan regions, a retrospective cohort study with 1,200 exposed children in Pernambuco State, between January 2000 and December 2009, revealed $9.16 \%$ of TTV, higher than here reported. ${ }^{26}$ These intraregional discrepancies even if admitting methodological biases, reinforces that, in the Northeast of Brazil, despite the successful national program to prevent TV, socioeconomic factors and health care failures are combined, resulting in great differences between locations, some with equivalent data such as the poor areas of the sub-Saharan Africa. 27 The fact that 96\% of patients who were researched in this study lived in the backlands of the San Francisco River and $23.2 \%$ of the sample proceeded in the countryside of Pernambuco State, would have expressed these two researches in a such more differences than the other two studies in the coastal region.
In our study, the MP were adequate and covered the three stages of care in only $31.6 \%$ of the cases. It is accepted that the MP effectiveness is based on the prior knowledge of HIV status. ${ }^{13,15-16}$ In the population studied, $26.3 \%$ knew about the situation too late, during childbirth or in the postpartum period. The study mentioned in Fortaleza reported higher percentage of adequacy - nearly $60 \%$ - and late detection was less $(21 \%)$ and TV $(2.5 \%)$ in a four year research. 21 In Aracaju, where TTV was observed, it was even lower (1.8\%), a complete MP protocol was applied in $31.8 \%$ of the cases, the percentage was almost identical to the one found in this study, but with low rate of late detection $(10.9 \%) .22$ It is pertinent to infer methodological differences is that, the greatest diagnostic failure found by us may have been a differential which led to delays and low percentage of MP adequacy with consequent outcomes of high TTV.

One reason to question this aspect, is the coverage and quality of prenatal care in both communities. While showing that $97.1 \%$ of the pregnant women had some attendance, our study, for data inconsistency did not quantify how many had reached the parameter of at least six consultations, using the MS to characterize prenatal care assistance. 13 It is known that the absence or inadequacy of prenatal care is a limiting factor to diagnose. 18-23 However, there is no consensus about what would be the ideal number of consultations, since, the availability of the quick test, the attendance in theory, would allow the diagnosis of HIV infection begin TARV and counseling for pregnant women. 15-16

This theory would favor the perception that the prenatal coverage has not been correspondingly accompanied by HIV testing. In the middle of the last decade the prevalence of prenatal care in the country was estimated at $96 \%$ and the national coverage of testing was $62.3 \%$, reaching between $24 \%$ and $40.6 \%$ in the Northeast Region. ${ }^{18,28}$ Between 2011 and 2012 the prenatal care coverage has advanced to a level of $98 \%$ with the coverage of the first HIV test at $81.7 \%$ at national plan and $68.4 \%$ in the Northeast. ${ }^{23}$ Data from the SISPRENATAL referring to the period of our study showed an average of 2.8 consultations per pregnant woman in the two cities, only $14.8 \%$ performed six or more attendance, while the coverage on HIV testing appears to be low $(30.1 \%)$, without reaching half of the national prevalence. ${ }^{19}$ These data reveal local failures at the diagnosis and the follow up of the pregnant women, which is already more striking than the different regional context. Therefore, it is important to benefit from all the possible contact 
with the pregnant women at the health services for quick testing and among other actions in care, prevention and health. $15-16$

The percentage achieved in stage $1(56.6 \%)$ was below the finding $(79.1 \%)$ in a similar study in Aracaju. 22 In addition, the median gestational age to diagnose (28 weeks) and time to apply TARV (13.5 weeks) reported about the delay at the beginning and the short duration of the intervention, in disagreement with the recommendation. 20 There are numbers that expose failures in important assistance, in a scientific context which has been increasingly demonstrated the effectiveness of ARV during the prenatal care, to reduce undetectable CV levels and catalyze the achievement of other MP. It is indisputable that its early applicability may benefit especially pregnant women with prior diagnosis. ${ }^{4,7,9}$

A consequence of the already discussed and missed opportunities in prenatal care, $15(19.7 \%)$ of the cases, the maternal diagnosis is only done at the delivery. Despite the regular availability of supplies at the hospitals during the study period, the injectable AZT was applied only in $61.8 \%$ of the population researched. It is worth mentioning that the MS considers AZT intrapartum an important marker of adequate implementation of prophylactic actions of TV of HIV.20 Its incomprehensive adoption indicates possible failures in care, going from the absence or the lack of preliminary screening to a not promptly outcome of the quick tests, with consequent delay in the decision of the childbirth - a compounded situation of rapid evolution or already advanced deliveries, which may have resulted in a low percentage of completion in Stage 2. This reinforces the thesis that, although it is essential to improve the quality of obstetric care, more important is to expand the serological diagnosis during pregnancy, so that the mothers may arrive at the maternity units with their status known and properly addressed. 16

In stage 3 ( $60.5 \%$ of complementation), the AZT syrup initiated in the maternities and maintained for six weeks in only $63.1 \%$ of the children provoked questions about the mothers' intolerance to the drug or failures on the follow up. No breastfeeding was the highest percentage of MP application $(79.0 \%)$, but because it is a less objective character and depends on the mothers' perception, adhesion and persistence level to question the degree of continuity of its use.

The five cases diagnosed with postpartum, plus the 15 intrapartum detected, means $26.3 \%$ of opportunities missed for TV prevention. Two mothers delivered at home, anticipating that, between 1994 and 2011, 45.5\% of home births in Brazil occurred in the Northeast region, a national context of $98.8 \%$ of hospital births. ${ }^{29}$ The occurrence of home births of HIV positive women reveal the social vulnerability of these women. Official data indicate $48.2 \%$ (Petrolina) and $79.7 \%$ (Juazeiro) the mean population of the Family Health Strategy coverage in both cities, in a five year research (currently $91.5 \%$ and 99.3\% respectively). 30 This tool for Primary Care could be better engaged in the identification and collection of these mothers, once overcome of the constant turnover of technical staff, guaranteed confidentiality and the discretion in contacting the patients.

This vulnerability also appears in the finding that non-white women were proportionately less favored in the diagnosis and in the adoption of MP at all stages of care. This result goes along with a national survey which showed a fewer results of the first HIV test in the North and Northeast regions especially in mulatto or black women, less schooling and whose prenatal care occurred in public clinics starting late and insufficient number of consultations, with a higher prevalence of HIV in self report as dark skinned.23 These characteristics are similar to the population here studied.

The shown data are equally eloquent to expose the relative lack of assistance to women in these surrounding cities. It is necessary to seek in loco extend to these communities, quick tests, counseling and at least the actions of stage 1 and 3, since the HDM references to obstetric care. The Health Network of Pernambuco and Bahia Interstates founded for more than five years to reorganize the assistance to health care in the middle region of the San Francisco River would be an institutional way to be engaged to promote this integration.

This study had limitations. The small " $n$ " allied to the event of low frequency and the exclusion of one in every four TTV cases restricting its analytical power. The high percentage of lack of MP information presumed the "non adoption", according to the logic of the FNI and the medical files register the assistance provided. The same criterion could not be attributed to the other variables, one, of utmost importance (measurement of maternal $\mathrm{CV}$ ), with a loss of $36.8 \%$. The fact that one of the cities has extrapolated its TTV affects the low percentage of MP adequacy observed. A less structured basic network and the demand of the cities may have been competing factors to be correlated with possibly late diagnoses, which may have delayed initially and restricted the time to use TARV, with the impact involvement of maternal CV. Such speculations are 
calling for more accurate analysis for its proof, impossible to compare the limitations described.

However, for being the first with this scope in the region reveals in its uniqueness to describe the application and adaptation of the MP of TV on HIV, a diagnosis of a situation in the countryside of the Northeast, performed in two cities. Showing high TTV, failure in the three stages of care, inadequacy in the adoption of MP and suggests racial inequality and between the cities its application. Comparing these results, attitudes should be imposed in short term and the minimal cost: increase and decentralize quick tests at pregnancy for everyone and any services, regardless of formal prenatal care; charge laboratories quick testing; integrate actions with the cities; improve the harmony between primary care and epidemiological surveillance, encouraging greater involvement of family health teams in identi- fying, following up and searching for mothers and children; offering reproductive planning; optimizing the pharmaceutical assistance with quick availability and constant supplies in the maternities and invest in training, awareness, and engagement of the obstetric teams. In the medium term, widen the prenatal care coverage to $100 \%$ with qualified and permanent teams.

\section{Acknowledgements}

To the preceptors at MINTER IMIP/ UNIVASF;

To the Sanitation Surveillance team in Petrolina, $\mathrm{PE}$ and Juazeiro, BA and other respective Referral Centers for STD/AIDS (COAS and CIDHA);

Dr. Aline Oliveira Cavalcanti for the encouragement, warmth and kind cooperation.

\section{References}

1. UNAIDS The Gap Report. 2014. [acesso em 20/10/2015]. Disponível em http://www.unaids.org/sites/default/files/en/ media/unaids/contentassets/documents/unaidspublication/2014/UNAIDS_Gap_report_en.pdf.

2. Rouzioux C, Costagliola D, Burgard M, Blanche S, Mayaux MJ, Griscelli C, Valleron AJ. Estimated timing of motherto-child human immunodeficiency virus type 1 (HIV-1) transmission by use of a Markov model. The HIV Infection in Newborns French Collaborative Study Group. Am J Epidemiol. 1995; 142: 1330-7.

3. Kourtis AP, Ibegbu CC, Wiener J, King CC, Tegha G, Kamwendo D, Kumwenda J, Kaur SP, Flax V, Ellington S, Kacheche Z, Kayira D, Chasela C, van der Horst C, Jamieson DJ. Role of intestinal mucosal integrity in HIV transmission to infants through breast-feeding: the BAN study. J Infect Dis. 2013; 208 (4): 653-61.

4. Joao EC, Gouvêa MI, Menezes JA, Sidi LC, Cruz ML, Berardo PT, Ceci L, Cardoso CA, Teixeira ML, Calvet GA, Matos HJ. Factors associated with viral load suppression in HIV-infected pregnant women in Rio de Janeiro, Brazil. Int J STD AIDS. 2012; 23 (1): 44.

5. Delicio AM, Milanez H, Amaral E, Morais SS, Lajos GJ, Silva JLCP, Cecatti JG. Mother-to-child transmission of human immunodeficiency virus in a ten years period. Reproductive Health. 2011; 8:35. Disponível em: http://www.reproductive-healthjournal.com/content/8/1/35.

6. Connor EM, Sperling RS, Gelber R, Kiselev P, Scott G, O'Sullivan MJ, VanDyke R, Bey M, Shearer W, Jacobson $\mathrm{RL}$, et al. Reduction of maternal-infant transmission of human immunodeficiency virus type 1 with zidovudine treatment. Pedriatic AIDS Clinical Trials Group Protocol 076 Study Group. N Engl J Med. 1994; 331: 1173-80.

7. Siegfried N, van der Merwe L, Brocklehurst P, Sint TT. Antiretrovirals for reducing the risk of mother-to-child transmission of HIV infection. 2011; Cochrane Database Syst Rev; (7): CD003510.

8. Rongkavilit C, Asmar BI. Advances in prevention of mother-to-child HIV transmission: the international perspectives. Indian J Pediatr. 2011; 78: 192-204.

9. Kim MH, Ahmed S, Preidis GA, Abrams EJ, Hosseinipour MC, Giordano TP, Chiao EY, Paul ME, Bhalakia A, Nanthuru D, Kazembe PN. Low rates of mother-to-child HIV transmission in a routine programmatic setting in Lilongwe, Malawi. PLoS One. 2013; 8 (5): e 64979.

10. Briand N, Warszawski J, Mandelbrot L, Dollfus C, Pannier $\mathrm{E}, \mathrm{Cravello} \mathrm{L}$ et al. Is intrapartum intravenous zidovudine for prevention of mother-to-child HIV-1 transmission still useful in the combination antiretroviral therapy era? Clin Infect Dis. 2013; 57 (6): 903-14.

11. Thome C, Patel D, Fiore S, Peckham C, Newell M-L and Members of the European Collaborative Study. Mother-tochild transmission of HIV infection in the era of highlya active antiretroviral therapy. Clin Infec Dis 2005; 40: 45865.

12. Rousseau CM, Nduati RW, Richardson BA, Steele MS, John-Stewart GC, Mbori-Ngacha DA et al. Longitudinal analysis of human immunodeficiency virus type 1 RNA in breast milk and of its relationship to infant infection and maternal disease. J Infect Dis. 2003; 187: 741-7.

13. Brasil. Ministério da Saúde. Secretaria de Vigilância em Saúde. Departamento de DST, Aids e Hepatites Virais. Protocolo clínico e diretrizes terapêuticas para prevenção da transmissão vertical do HIV, sífilis e hepatites virais. Brasília, DF; 2015.

14. Brasil. Ministério da Saúde. Portaria ministerial no 2104. Institui, no âmbito do Sistema Único de Saúde/SUS, o Projeto Nascer-Maternidades. Diário Oficial da União 2002; 19 nov. 
15. Brasil. Portaria $\mathrm{MS} / \mathrm{GM} \mathrm{n}^{\circ}$ 77. Dispõe sobre a realização de testes rápidos, na atenção básica, para a detecção de HIV e sífilis, assim como testes rápidos para outros agravos, no âmbito da atenção prénatal para gestantes e suas parcerias sexuais. Diário Oficial da União 2012; 12 jan.

16. Matida, LH, Gianna, MC, Tayra, A, Gonçalves DA. Guia de referências técnicas e programáticas para eliminação da transmissão vertical do HIV/Guide to technical and programmatic references for elimination of vertical transmission of HIV. São Paulo: Centro de Referência e Treinamento em DST/Aids; SES; 2014.

17. Brasil. Ministério da Saúde. Plano Operacional de Redução da Transmissão Vertical do HIV e da Sífilis. Brasília, DF; 2007

18. Souza Junior PRB, Szwarcwald CL, Barbosa Júnior A, Carvalho MF, Castilho EA. Infecção pelo HIV durante a gestação: Estudo-Sentinela Parturiente, Brasil, 2002. Rev Saúde Pública. 2004; 38: 764 -72.

19. Brasil. Ministério da Saúde. DATASUS. Programa de imunização no pré-natal e nascimento. Relatórios de gestantes cadastradas e frequências de consultas nos municípios de Petrolina/PE e Juazeiro/BA, competências 2006 a 2010. Petrolina, PE; Juazeiro, BA; 2011.

20. Brasil. Ministério da Saúde. Secretaria de Vigilância em Saúde. Programa Nacional de DST e Aids. Recomendações para profilaxia da transmissão vertical do HIV e terapia antirretroviral em gestantes. Brasília, DF; 2010.

21. Lopes DSV. Epidemiologia da transmissão vertical do HIV em Fortaleza, 2002-2005. Epidemiology of vertical HIV transmission in Fortaleza, 2002-2005 [dissertação]. Rio de Janeiro: Instituto de Comunicação e Informação Científica e Tecnológica/Biblioteca de Saúde Pública; 2008.

22. Lemos LMD, Rocha TFS, Conceição MV, Silva Eduardo L, Santos AHS, Gurgel RQ. Evaluation of preventive measures for mother-to-child transmission of HIV in Aracaju, State of Sergipe, Brazil/Avaliação das ações de prevenção da transmissão materno-infantil do HIV em Aracaju, Estado de Sergipe, Brasil. Rev Soc Bras Med Trop. 2012; 45 (6): 682-6.

Received on February 15, 2016

Final version presented on August 15, 2016

Approved on September 20, 2016
23. Domingues RM, Szwarcwald CL, Souza PR, Leal Mdo C. Prenatal testing and prevalence of HIV infection during pregnancy: data from the "Birth in Brazil" study, a national hospital-based study. BMC Infect Dis. 2015; 15: 100.

24. Vasconcelos ALR, Hahmann EM. Porque o Brasil registra elevados coeficientes de transmissão vertical do HIV? Uma avaliação da qualidade da assistência prestada a gestantes/parturientes infectadas pelo HIV e seus recémnascidos. Rev Bras Saúde Matern Infant. 2005; 5: 483-92.

25. Brasil. Ministério da Saúde. Secretaria de Vigilância em Saúde. Departamento de DST, Aids e Hepatites Virais. Boletim Epidemiológico HIV/Aids. Brasília, DF; 2015.

26. Cruz Gouveia PA, Silva GA, Fátima PMAM. Factors associated with mother-to-child transmission of the human immunodeficiency virus in Pernambuco, Brazil, 20002009. Trop Med Int Health. 2013; 18 (3): 276-85.

27. Kerr LR1, Cavalcante MS, Kendall C, Machado MM, Dourado MI, Galvão M. Disparities in mother-to-child transmission in Northeast Brazil: regional failures within successful country programs. AIDS Care. 2011; 23 (6): $771-4$.

28. Szwarcwald CL, Barbosa Júnior A, Souza Júnior PR, Lemos KR, Frias, PG, Luhm KR, Holcman MM, Esteves MA. HIV testing during pregnancy: use of secondary data to estimate 2006 test coverage and prevalence in Brazil. Braz J Infect Dis. 2008; 3: 167-72.

29. Carvalho IS, Costa PF, Oliveira JC, Brito RS. Perfil epidemiológico de partos e nascimentos ocorridos no domicílio: um estudo ecológico. Epidemiological profile of parturitions and births occurring at home: an ecological study. Perfil epidemiológico de partos y nacimientos ocurridos en el hogar: un estudio ecológico. Rev Enferm UFPE. 2014; 8 (Supl. 2): 3847-54.

30. Brasil. Ministério da Saúde/SAS/Departamento de Atenção Básica - DAB. Portal da Saúde [acesso em 01/08/2016]. Disponível em: http://dab.saude.gov.br/portaldab/historico cobertura_sf.php. 